Sleijpen, M., Boeije, H.R., Kleber, R.J., Mooren, T. Between power and powerlessness: a metaethnography of sources of resilience in young refugees. Ethnicity and Health: 2016, 21(2), 158180

\begin{tabular}{|l|l|}
\hline $\begin{array}{l}\text { Postprint } \\
\text { Version }\end{array}$ & 1.0 \\
\hline $\begin{array}{l}\text { Journal website } \\
\text { Pubmed link }\end{array}$ & $\frac{\text { http://www.tandfonline.com/doi/abs/10.1080/13557858.2015.1044946?journalCo }}{\underline{\text { he=ceth20 }}}$ \\
\hline DOI & $10.1080 / 135 w$.ncbi.nlm.nih.gov/pubmed/26107385 \\
\hline
\end{tabular}

This is a NIVEL certified Post Print, more info at http://www.nivel.eu

\title{
Between power and powerlessness: a meta- ethnography of sources of resilience in young refugees
}

\author{
MARIEKE SLeIJPEN ${ }^{\mathrm{AB}}$, HeNNIE R. BOEIJE ${ }^{\mathrm{C}}$, ROLF J. KLEBER ${ }^{\mathrm{AB}} \&$ TRUDY MOOREN $^{\mathrm{AD}}$
}

\begin{abstract}
Objective. This article reviews available qualitative studies that report young refugees' ways of dealing with adversity to address their sources of resilience.

Design. We searched five electronic databases. Twenty-six empirical studies were included in the review. A meta-ethnography approach was used to synthesize these qualitative studies.

Results. Six sources of resilience emerged: (1) social support, (2) acculturation strategies, (3) education, (4) religion, (5) avoidance, and (6) hope. These sources indicated social as well as personal factors that confer resilience in young refugees, but most of them also had counterproductive aspects.

Conclusion. The results, from an ecological developmental perspective, stressed the interplay between protective and risk processes in the mental health of young refugees who had resettled in Western countries, and they emphasized the variability as well as the universality of resilience-promoting processes. Further research is needed to explore the cultural shape of resilience and the long-term consequences of war and migration on young refugees.
\end{abstract}

\section{INTRODUCTION}

Children and adolescents who have fled their countries because of war or persecution and who resettle in Western countries need to adapt to constantly changing societal conditions. After their flight, they not only have to deal with complex legal immigration processes and their trauma history, but also with the social, cultural, and linguistic differences between their places of origin and their new settings. These conditions put young refugees at serious risk of developing a range of health problems, which include post-traumatic stress disorder (PTSD), mood disorders, and emotional and behavioral problems (Bronstein and Montgomery 2011; Fazel et al. 2012; Lustig et al. 2004).

Western models of illness commonly frame young refugees' responses to stressors in terms of psychopathology. A number of studies have highlighted the importance of the concept of PTSD in understanding and treating young refugees (Hodes 2000; 
Sleijpen, M., Boeije, H.R., Kleber, R.J., Mooren, T. Between power and powerlessness: a metaethnography of sources of resilience in young refugees. Ethnicity and Health: 2016, 21(2), 158180

Kinzie et al. 1986). Some authors have, however, criticized this approach as overmedicalizing (Kleber 1995; Papadopoulos1999), oversimplifying (Richman 1993), and being culturally inappropriate (Bracken, Giller, and Summerfield 1995; Hinton2000). These criticisms stress the importance of considering the wider social, political, and cultural context in which the life of young refugees is embedded (Reed et al. 2012).

In response, some researchers have started to emphasize positive aspects, including these youth's resilience in the face of adversity (Pacione, Measham, and Rousseau 2013). For example, McMullen et al. (2012) showed that many war-affected adolescents from Uganda did not display psychosocial distress four years after the war had ended, despite witnessing various atrocities. Sutton et al. (2006) highlighted the fact that ongoing distress and posttraumatic growth coexist in adolescent refugee populations. The emphasis on resilience aims to determine which pathways lead to positive adjustment and development (e.g., Clay, Knibbs, and Joseph 2009; Tedeschi and Calhoun 2004). Not only do risk factors need to be explored but also protective factors that enhance a person's capacity to face and to transcend adversity (Michaud 2006).

Although the relevance of a resilience-oriented approach is broadly recognized, there is little consensus about the definition of resilience (e.g., Brom and Kleber 2009).

Resilience has been defined as an individual trait that helps an individual to function well despite exposure to considerable adversity (Block and Block 1980), and also as a dynamic developmental process reflecting evidence of positive adaptation despite significant life adversity (Masten 2001). In addition to definition differences, there are substantial variations in the operationalization and measurement of resilience (Luthar, Cicchetti, and Becker 2000). One challenge in measuring resilience in young refugees is the issue of cross-cultural equivalence. Wyman (2003) argued that processes that are beneficial to adolescents in one context may have no or even harmful effects in another context. Using Western instruments to measure resilience in non-Western groups might be of limited value because hidden resilience sources, which may not come to the notice of those who define resilience from a Western perspective, can be missed (Ungar 2012).

The challenge to account for the sociocultural context in which resilience occurs can be addressed by qualitative research. Qualitative methodology is suitable to describe a phenomenon in special contexts, to give power to minority 'voices' and to supplicate researchers to account for their own biased standpoints when working with research participants from different cultural and linguistic backgrounds (Ungar 2003). In view of the limited information available about resilience of young refugees and given the confusion about the construct, qualitative methods can be useful to discover unnamed sources of resilience relevant to this specific group. In order to achieve a better understanding of the way adolescent refugees deal with adversity and the contextual factors which contribute to resilience in this group, we conducted a meta-ethnographic analysis of relevant qualitative studies. Qualitative research can provide insight into the meanings that events and sources have for individuals and groups in different contexts. We examined young refugees' sources of resilience, and cross-cultural similarities and differences therein. By synthesizing different qualitative studies, we were able to expand the scope of the analysis by integrating multiple voices with different cultural backgrounds in pursuit of a new interpretation (Doyle 2003). A better conceptual understanding of young refugees' 
Sleijpen, M., Boeije, H.R., Kleber, R.J., Mooren, T. Between power and powerlessness: a metaethnography of sources of resilience in young refugees. Ethnicity and Health: 2016, 21(2), 158180

needs and sources of resilience can be used to inform development of preventive and therapeutic interventions.

\section{METHOD}

\section{Qualitative synthesis methodology}

Our synthesis was guided by the principles of meta-ethnography (Campbell et al. 2003; Noblit and Hare 1988), which enables the reviewer to understand and to synthesize the findings of qualitative studies concerning a similar review question. This method permits cross-study comparison (Smith, Pope, and Botha 2005) and provides a systematic approach while maintaining the interpretive properties of the original articles (Dixon-Woods et al. 2005).

\section{Search strategy}

We systematically searched five electronic databases (CINAHL, Embase, Pilots, PsycINFO (via OVID), and Pubmed) from inception until the end of 2011 and later we searched for updates in all databases through June 2013. Furthermore, we scanned reference lists of the included articles. The keywords used are: refugee, adolescent, qualitative research and resilience (see for a complete presentation, Table 1). Search terms were used in combination, by adding the Boolean operators 'AND' and 'OR'.

We deliberately looked for articles about resilience in the broadest sense because it is a term that has been widely used only recently. This means that studies had to address sources of support or ways of dealing with all kinds of adversity and stress expressed by young refugees.

\section{[TABLE 1]}

\section{[FIGURE 1]}

\section{Study selection}

Only studies that met the following selection criteria were considered for inclusion in the review (see Figure 1):

Written in the English language.

Published in a peer-reviewed journal.

Used qualitative research design or used a mixed-methods design in which it was possible to separate the results of the qualitative component from the results of the quantitative component (Boeije, Van Wesel, and Slagt 2014).

Included participants between the ages of (on average) 10 and 20 years. Studies that reported the retrospective view of adults about their childhood or only the perspective of related adults (such as caregivers, family members, key informants, or health-care professionals) were excluded.

Focused on refugees and asylum seekers. Studies about internally displaced persons were excluded. Furthermore, studies were excluded that did not clearly distinguish refugee groups from other possible research groups, such as other ethnic minorities. Titles and abstracts of the first 200 articles were scanned for relevance by two reviewers (MS; HB). No differences were found between the two reviewers. One reviewer (MS) scanned the remaining articles, and those that appeared to meet the inclusion criteria were obtained in full. Then the full text was read by two reviewers 
Sleijpen, M., Boeije, H.R., Kleber, R.J., Mooren, T. Between power and powerlessness: a metaethnography of sources of resilience in young refugees. Ethnicity and Health: 2016, 21(2), 158180

(MS; TM). Differences in decisions between the reviewers were discussed until consensus was reached, and articles that met the inclusion criteria were included. A total of 26 studies remained. Table 2 provides a summary of the articles included in the synthesis.

\section{[TABLE 2]}

\section{Quality appraisal}

All 26 studies were appraised using the Critical Review Form (Letts et al. 2007a, 2007b; see Table 3), which contains 12 items to be scored as either ' 1 ' (criterion is met) or ' 0 ' (criterion is not reported or is insufficiently addressed). First, two reviewers (MS; HB) independently assessed six articles. Scores were discussed until consensus was reached. The other articles were appraised by either of the two reviewers, followed by collaborative discussions when doubt existed. The findings from these appraisals were not used to include nor to exclude studies, as no accepted methods to guide these decisions have yet been created (Boeije, Van Wesel, and Alisic 2011; Thomas and Harden 2008).

\section{[TABLE 3]}

\section{Data analysis}

We based our syntheses of qualitative studies on the seven-phase synthesis approach of Noblit and Hare, outlined in the original description of meta-ethnography (Noblit and Hare 1988). These phases can overlap and be carried out simultaneously (France et al. 2014). Since some steps are not clearly delineated, for example the analytic process of synthesizing (Atkins et al.2008), we also were informed by a number of existing reviews. Table 4 gives an overview of how we performed the seven phases.

\section{[TABLE 4]}

\section{RESULTS}

\section{Quantity and quality of included studies}

From the literature search, we identified 26 studies that satisfied the inclusion criteria, and these were published between 1988 and 2013. These studies used a variety of data collection methods, including: interviews, focus groups, observations, and visual methods. Sample size varied widely from 4 to 123 participants. The studies were conducted in several continents (North America: 14 studies; Australia: 5 studies; Europe: 6 studies). Study populations consisted either of participants from different ethnic backgrounds (12 studies) or of homogenous ethnical groups (14 studies). Three studies included only boys (3, 7, and 20), and seven studies focused on unaccompanied refugee youth $(7,9,12,15,16,20$, and 23). Additionally, Studies 4 and 5 as well as Studies 15 and 16 used the same group of participants, but they discussed different topics.

The quality of the included studies ranged between 4 and 11 out of 12 on the quality appraisal tool. Most articles had a clear purpose, a relevant literature review, and a suitable conclusion, but lacked a proper description of the sampling strategies and auditability of the analyses. 
Sleijpen, M., Boeije, H.R., Kleber, R.J., Mooren, T. Between power and powerlessness: a metaethnography of sources of resilience in young refugees. Ethnicity and Health: 2016, 21(2), 158180

\section{Sources of resilience}

In the included studies, young refugees mentioned several factors that helped them to deal with traumatic memories and to cope with their turbulent lives. Six key sources recurred: social support, acculturation strategies, education, religion, avoidance, and hope. These sources of resilience are related to different domains: attributes and capacities of the youth themselves, aspects of their family and immediate vicinity, and characteristics of their wider social and political environments. Additionally, most of the sources of resilience seemed to have a flip side.

\section{Social support}

The identified literature revealed that social support is a substantial factor that influenced the process of dealing with problems on a number of different levels $(1,2$, $4,6-9,12-15,17-20,23,25$, and 26). The most frequently mentioned sources of support were (1) family, (2) people from the same cultural background, (3) peers, and (4) professionals. Although several papers reported the importance of sharing problems with others, other papers discussed the refugees' need to handle problems on their own as well as their hesitance to trust others $(1,8,9,15$, and 18).

\section{Family}

Numerous young refugees sought support and guidance from family and had a strong sense of family cohesion $(2,8,13,14,18,25$, and 26). Younger participants in particular appreciated assistance from their parents (18). Some did not identify their parents or family as potential sources of social support and had two main reasons for not doing so. First, they did not want to bother their parents/family because these people already had too many (mental) problems and worries associated with the war and resettlement stress $(1,4,8,10$, and 26). Second, the youth considered turning to their parents/family to be too complicated because these youth believed cultural rules of the family conflicted with the rules of the host country. The differences between young refugees' own acculturation processes and their parents' acculturation caused intergenerational problems $(4,8,10,13,18,19$, and 22). Consequently, young refugees kept some things secret from their parents.

\section{People with the same cultural background}

Young refugees perceived people who shared the same culture as significant sources of support in, for example, reducing their sense of threat posed by change as well as their sense of cultural loss $(7,8,12,15,17,18,20$, and 25). Contact with culturally similar others provided opportunities for continuity of culture and conversation. Although these relationships functioned as an affirmation of collective identity, several refugees also mentioned the risk of isolation from the host society associated with being close only to culturally similar others (12, 20, and 25).

\section{Peers}

Young refugees identified peers as a major source of help because they distracted them from problems and gave them advice about, for example, adjusting to the new country $(1,2,4,8,9$, and 26). Personal issues were sometimes shared with friends and not with parents because peers understood them better and knew what they were going through (1). Despite this belief, young refugees indicated being cautious in totally trusting their peers (1 and 9). 
Sleijpen, M., Boeije, H.R., Kleber, R.J., Mooren, T. Between power and powerlessness: a metaethnography of sources of resilience in young refugees. Ethnicity and Health: 2016, 21(2), 158180

\section{Professionals}

In five studies $(4,8,9,23$, and 26), young refugees expressed their belief in the importance of professionals (social workers, school tutors, school counselors, and social services) because they helped them to meet basic needs and gave practical advice. However, participants discussed their lack of knowledge about mental health services, their distrust, and the social stigma of mental health services $(1,4,8,9$, and 18). The use of mental health services was often at odds with their culture of origin. For example, some young refugees (especially girls) reported that they would not access a mental health service if the staff included professionals of the same culture because such people might have contact with their family or social community (1). In contrast, others described the lack of ethno-specific workers as a barrier to access mental health services (8). In both cases, 'trusting the therapist' appeared to be the underlying problem.

\section{Acculturation strategies}

Young refugees mentioned the coping strategy of connecting to the culture or region of origin $(8,14,15,17,18$, and 25$)$ as well as adapting to a new lifestyle $(5,6,8,12$, $13,15,17,18,19$, and 22). They expressed their ambivalence about embracing a new culture while remaining loyal to the old one. They seemed to find adjusting to the new culture without forgetting their own culture the most desirable outcome. Adaptation to the new lifestyle and surroundings helped young refugees to gain social acceptance and to strengthen their sense of self. Learning the new language, studying the new culture, and affiliating with peers from the new country were seen as essential acculturation strategies. These changes and challenges, however, caused distress. They mentioned learning the new language, for example, as a major source of stress: it contributed to feelings of insecurity about making new friends and created difficulties with academic studies $(3,8,10,13,14,18,19,22,24$, and 26). The process of adaption to the new country seemed to be easier for refugees who came to the host country at a younger age than for those coming in at older ages $(6$, 11). Furthermore, the results of Study 26 demonstrated that refugees with less language transition had better psychosocial adjustment.

Some of the youth tried to avoid being seen as different by minimizing their uniqueness and avoiding talking about traumatic experiences. At times, trying to fit in seemed a response to the experience of being misunderstood by peers and to discrimination. Many studies found that young refugees experienced forms of discrimination in relation to several aspects of their social identity, like religion, race, and ethnicity $(1,5,6,9,10,12,13,17-19$, and 22).

\section{Education}

Young refugees placed a high value on education $(6,7,9,11,12,17$, and 24-26). They saw education and knowledge as the primary way of gaining control over their lives, as the key to a higher status, and as a way out of their current lives and their disempowered positions. The desire to succeed and to meet family expectations, however, increased the burden of responsibility and led to fear of failure $(6,9$, and 11). Several young refugees stressed their feeling that because they belonged to a racial or social minority and a low socioeconomic group, they had to struggle harder in order to succeed. This challenged some of them to work harder, to study more, and to do better than their peers (17). 
Sleijpen, M., Boeije, H.R., Kleber, R.J., Mooren, T. Between power and powerlessness: a metaethnography of sources of resilience in young refugees. Ethnicity and Health: 2016, 21(2), 158180

\section{Religion}

The process of thinking about what had happened and why it had happened appeared to be beneficial for young refugees. The role of religion was especially relevant in this process $(3,4,7,8,15,16,23,25$, and 26). Religion had different functions: (1) a guide for how to lead their lives; (2) a facilitator for the development of meaning and acceptance in coming to terms with adversity; (3) a source of support (for example, some refugees received support from other church members or had a relationship of confidence with God); (4) a source of continuity (faith and associated rituals remained, among only a few things, relatively unchanged for the young refugees); (5) a source of distraction; and (6) a source of strength that kept them going during difficult moments and helped them to feel a sense of control over their lives. Although religious coping was available in young refugees' circumstances, its use was hindered when their new peers were unaccustomed to the religion and related activities and perceived them negatively (16).

\section{Avoidance}

Avoidance was a central theme in the included studies (6-9, 12, 23, and 25). Young refugees described suppression of traumatic memories as an effective coping strategy because it enabled them not to be overwhelmed by their thoughts and to continue with their lives. Closely related to the coping strategy of suppression was distraction. Distraction was, for young refugees, a way to suppress difficult thoughts. For example, spending time with friends and keeping busy with school or sports took their mind off their problems, decreased their stress, and gave them the feeling of power to cope. Boredom had, therefore, the opposite result.

Some of the young refugees emphasized the fact that even though they realized that avoiding problems could have negative consequences in the long term, it was appropriate at times (8). Avoiding painful thoughts and feelings could be viewed as a way of managing an unstable, uncontrollable, and potentially threatening environment: for example, the continuous fear of deportation experienced throughout the asylum procedure $(7,9$, and 15$)$.

\section{Hope}

Many young refugees had clear goals, and some refugees were hopeful about the future $(6,7,11,15,18,23$, and 26). Their sense of hope served as a powerful source of positivity and facilitated their coping with their difficult present-life circumstances $(7,11,15$, and 18). Narratives of young refugees who had endured trauma and loss presented the transition from hopelessness to hope in their lives (7 and 15). They appear to have perceived hope as having 'possibilities' for a better future rather than as having 'expectations.' They talked about creating a better future for themselves and of searching for new hope. The opportunity to have an education (see heading above) provided, for example, a sense of hope for future success.

\section{Cultural differences and similarities}

Young refugees from different countries of origin noted the differences between their original lifestyles and Western lifestyles. In addition, they recognized the role of culture and described how their own community, cultural norms, and traditions gave them strength. While participants originated from a wide range of cultural 
Sleijpen, M., Boeije, H.R., Kleber, R.J., Mooren, T. Between power and powerlessness: a metaethnography of sources of resilience in young refugees. Ethnicity and Health: 2016, 21(2), 158180

backgrounds, their responses had much in common, and they showed many niver similarities in their actions and ways of thinking $(1,5,7,8,11,16$, and 18). Some researchers emphasized the difficulties in formulating generalizations at the cost of cultural specificity as well. Although many authors stressed the importance of examining the specific experiences of different cultural groups, clear descriptions, illustrations, or explanations for this statement were only rarely given. Only two studies, with a heterogenic study population, explicated differences between refugee groups from different cultural backgrounds (1 and 26). The young refugees who were familiar with modern society and the languages of the host country seem to have adjusted more easily than did the young refugees who were not. Furthermore, African refugees were more likely to seek for help by spiritual traditional remedies than were refugees from other regions (1). Overall, the authors of most of the included studies suggested that there are cultural differences in ways of dealing with adversity, but most of the studies lacked the empirical evidence required to provide a more nuanced account of the distinctions between cultures.

Several researchers described similarities between adolescent refugees and adolescents in general $(6,8,10,11$, and 23$)$. Adolescent refugees were, like adolescents in general, more likely than adults to seek support from those around them rather than from the professional health sector. Their dual need for independence and adult protection, the increase in peer group influence, and identity development are processes that are universal in adolescence, although some of these processes are more pronounced in adolescent refugees.

\section{DISCUSSION}

We synthesized the results of 26 qualitative studies that explored the way young refugees deal with hardship and stress. Six sources of resilience stood out: social support, acculturation strategies, education, religion, avoidance, and hope. The individual adolescents' own capacities and their larger social environment, as well as the interactions between them, helped young refugees to deal with the adversities of being a refugee and living in a new country. In addition, all studies addressed both risk and protective factors (i.e. vulnerabilities and strengths, sources of power and powerlessness). The results demonstrated that we cannot consider refugee youth as either 'vulnerable' or 'resilient.' These findings revealed a dynamic process that fosters resilience in refugee youth and supported the ecological model, a contextdriven approach that focuses on the dynamic interactions among various personal and environmental factors, to understand risk, stress, and protective factors associated with mental health (Bronstein, Montgomery, and Ott 2013).

It also became clear that refugee groups from different countries of origin show many similarities in their sources of resilience. Although young refugees face several different challenges, basic needs (such as feeling safe, having meaningful relations with family and peers, and having opportunities for personal growth) and fundamental coping strategies (such as seeking support from others, finding hope, and finding meaningful distractions) are not unique but universal to adolescence (e.g., McCarthy and Marks 2010). Still, the sociocultural background of refugees was found to promote factors that contributed to their resilience, such as their spirituality and cultural traditions. This finding highlights the fact that resilience processes have universal as well as specific, culturally based components. 
Sleijpen, M., Boeije, H.R., Kleber, R.J., Mooren, T. Between power and powerlessness: a metaethnography of sources of resilience in young refugees. Ethnicity and Health: 2016, 21(2), 158180

Five of the six sources of resilience (social support, acculturation strategies, nivel education, religion, and avoidance) also had counterproductive aspects. Depending on the demands of the situation, these sources were less beneficial or even had a negative influence on adjustment processes in young refugees (see Table 5). This duality represents the diversity of experiences of young refugees and the need to address differences, flexibility, individuality, and changes over time. For example, some young refugees were positively challenged to succeed in education despite adverse circumstances, while others became discouraged when adversity accumulated over time. Furthermore, the six sources were related and overlapped with regard to their functionality. Education, for example, provided hope, and both social support and education made distraction possible.

\section{[TABLE 5]}

The sources of resilience were particularly used to achieve some basic needs: feeling safe and secure, having a sense of personal control, maintaining self-esteem, having meaningful relationships, and reducing stress. In particular, a sense of personal control stood out. This result confirms previous findings that feeling powerless is a major issue in young refugees' lives (Gustafsson, Fioretos, and Norström 2012). Many studies in the field of (traumatic) stress have shown that personal feelings of mastery clearly have a positive impact on the mental and physical health of individuals, irrespective of the seriousness of the situation (Kleber and Brom 2003). In addition, we found that adolescents without the legal status of a refugee were especially limited in their freedom. The possibility of being sent back to their countries of origin caused ongoing sources of stress and the feeling that their lives were at the mercy of others.

Several included studies provided more information about how young refugees deal with daily stress and adapt to new cultures than information about how they cope with their (traumatic) histories. Perhaps young refugees are not ready to handle the past because the present is not stable yet, or their 'pre-refugee life' is often shorter and therefore less active than their 'refugee life.' This might depend on the age at which they arrive in the host country. Other explanations are that the researchers devoted more attention to psychosocial adjustment than to trauma history and that the young refugees were not willing to talk about their past because it was too traumatic. Nevertheless, the results indicated, in agreement with quantitative studies, that post-migration stressors (e.g., discrimination, communication problems, uncertainty about residence status) have a major impact on young refugees' mental health (Henley and Robinson 2011; Porter and Haslam 2005; Silove et al. 1998). The data showed that adolescent refugees live between two cultures: they are too young to identify completely with their country of origin and too old to identify completely and directly with the host country. They try hard to build bridges, learn the language, and open lines of communication to the 'new world,' and consequently they adapt much easier than do adults. Such a bicultural involvement appears to be a positive predictor of psychological well-being and mental health (e.g., Knipscheer and Kleber 2006). Nevertheless, the results showed that for young refugees this bicultural focus also may cause intergenerational strains and the possibility that too early they must assume adult roles, such as by interpreting for their parents or taking on employment (see also Leavey et al. 2004). Overall, we can conclude that young refugees are on the intersections of child and adult, refugee and citizen of the host 
Sleijpen, M., Boeije, H.R., Kleber, R.J., Mooren, T. Between power and powerlessness: a metaethnography of sources of resilience in young refugees. Ethnicity and Health: 2016, 21(2), 158180

country, powerful and powerless, culturally specific and universal. Being aware of niver these binary notions, we can create a more nuanced picture of young refugees' lived experiences (O’Higgins 2012).

In order to be up to date, we refreshed our search in all databases to include studies between June 2013 and February 2015. We found four new articles (Betancourt et al. 2015; Ndedngeyingoma, De Montigny, and Miron 2013; Thommesssen, Corcoran, and Todd 2015; Weine et al. 2014). The results of these studies were in line with our results: The importance of the ecological model and the facilitating influences of school, social support, and acculturation strategies were strengthened after reviewing these publications. Besides, the themes of discrimination, the constraining component of family dynamics (Betancourt et al. 2015;

Ndedngeyingoma, De Montigny, and Miron 2013) and responsibility (Ndedngeyingoma, De Montigny, and Miron 2013; Thommesssen, Corcoran, and Todd 2015) were discussed in some of these studies as well. Regarding religion, Betancourt et al. (2015) and Weine et al. (2014) described religion as protective resource that can promote young refugees' psychosocial well-being. On the other hand, Ndengeyingoma and collegues (2013) revealed that it was hard for many young refugees to maintain their religious beliefs in the new country and that some of them were reconsidering their religious engagement in favor of making friends. Furthermore, participants in this study indicated that they felt they had to live at least four years in the host country in order to understand the culture and history of the new country.

\section{Strengths and limitations}

As a multidisciplinary team, we utilized established methods to review studies that span multiple qualitative methodological, theoretical perspectives, and social and political contexts. Doing this allowed us to reinterpret meaning across different qualitative studies and to generate configurations about refugee youth's own understanding of risk and resilience. We chose the meta-ethnography approach because this is one of the few meta-synthesis approaches that require researchers to address incongruities and inconsistencies (Booth et al. 2013).

Nevertheless, the multi-context approach of this qualitative synthesis also has weaknesses. We found a great variety in study populations and in main topics between and within the included studies (such as with regard to age and length of stay in the host country). This heterogeneity prevented the evaluation of contextual and age-specific factors and the assurance that data saturation was reached; nevertheless, we found evidence for sources of resilience supported by a large group that were considered effective for dealing with different types of adversity. Furthermore, even the context-specific-included studies could have missed cultural differences: young refugees' not commenting on particular cultural influences does not mean the influences do not exist. In addition, synthesizing qualitative research with different philosophical assumptions attracts criticism (Barbour and Barbour 2003) as the original theoretical orientation of each study gets lost when it is synthesized (Atkins et al. 2008). And although our search was extensive, it was limited to studies published in English, and gray literature was not included. This limitation negatively influences the generalizability of our results, for example, with regard to non-Western countries. 
Sleijpen, M., Boeije, H.R., Kleber, R.J., Mooren, T. Between power and powerlessness: a metaethnography of sources of resilience in young refugees. Ethnicity and Health: 2016, 21(2), 158180

\section{Future research}

A further contextual understanding of resilience processes in young refugees and their practical and emotional stresses is needed to guide clinical practice and the development of suitable support. Studies with youth from different cultural backgrounds should question further to what extent resilience processes are universal (comparable across populations) or specific (different in their effectiveness according to adolescence's social context and individual legacy). Combining context-specific qualitative-evidence syntheses (QES) with multi-context QES can give a comprehensive picture about culture and contextual sources of resilience by transcultural modification and trans-contextual adaptation (Hannes and Harden 2011). Furthermore, longitudinal studies are needed to better understand the developmental factors associated with trauma, acculturation, and resilience processes.

Qualitative research provides answers to questions about why young refugees behave in particular ways, and it accounts for cross-cultural diversity (Ungar and Nichol 2002). Regarding the quality of the qualitative studies, however, the results of our quality appraisal demonstrated room for improvement. Acknowledging traps and difficulties in qualitative research might help to guide new efforts to achieve academic excellence (Kapoulas and Mitic 2012). Moreover, combining in-depth stories with general conclusions, by mixing qualitative methods with quantitative methods, might give us a more comprehensive understanding of resilience in refugee youth.

\section{Practical implications}

From the results of this synthesis, we can conclude that there are sufficient resilience factors beyond individual characteristics that can be modified by outside intervention or by policy (Betancourt and Khan 2008), for example, by improving access to educational opportunities. The results demonstrated that the parents' ability to provide a buffering role depends on their capacity to maintain a healthy family. Consequently, we have to look at the interchange between the different life spheres when dealing with traumatized refugee families, and family intervention might be effective.

With regard to mental health services, the results revealed that young refugees in general have little knowledge of and experience with problems accessing this type of support. They have to deal with multiple issues and are therefore referred to different services every time another problem arises. More low-key information about mental health services (for example at school; Ellis, Lincoln, et al. 2010) and the co-location of services might increase youth's engagement in treatment (Ungar2011).

The importance of the time factor when people work with young refugees' adjustment processes must be acknowledged. These youth need time to trust others, to feel safe, and to adapt to the changing conditions. If the daily stressors are too demanding, no room is left for processing traumatic memories. Establishing a place of safety is essential to facilitating an exploration of traumatic experiences in a therapeutic sense. Additionally, creating a sense of continuity in their constant changing circumstances can be helpful for their development (e.g., Mazumdar and Mazumdar 2009).

Feelings of uncertainty and powerlessness were present in many young refugees. Traumatic experiences in the past fueled their uncertainty, and their position in their host country often reinforced this uncertainty. In light of this finding, we think that 
Sleijpen, M., Boeije, H.R., Kleber, R.J., Mooren, T. Between power and powerlessness: a metaethnography of sources of resilience in young refugees. Ethnicity and Health: 2016, 21(2), 158180

offering young refugees more opportunities to acquire a meaningful role in their nivel social environments can reduce their sense of powerlessness and give them strength (see also Betancourt 2005; Ryan, Benson, and Dooley 2008). We must recognize their abilities, their power, and their potential instead of focusing only on their vulnerabilities (Sleijpen et al. 2013).

\section{CONCLUSION}

Resilience of young refugees cannot be described in a static nor in a one-dimensional way. War and political violence destroy the infrastructure of daily life at precisely the phase in life when children need reliable social structures to reassure them. Nevertheless, our results showed that refugee adolescents feel responsible, albeit forced, to resolve their problems, and they are able to cope with many stressors in a creative way. The results addressed the interplay between risk and resilience processes in the mental health of young refugees from an ecological developmental perspective. We need to listen to what young refugees have to say and give them the opportunities to develop their potential without ignoring their vulnerabilities in order to avoid having their lives' be on hold for too long.

\section{Acknowledgments}

We thank F. Jackie June ter Heide for editing the final text.

\section{Disclosure statement}

The authors declared no potential conflicts of interest with respect to the research, authorship, and/or publication of this article

\section{REFERENCES}

Anstiss, de Helena, and Tahereh Ziaian. 2010. "Mental Health Help-seeking and Refugee Adolescents: Qualitative Findings from a Mixed-methods Investigation.” Australian Psychologist 45 (1): 29-37. doi:10.1080/00050060903262387.

Atkins, Salla, Simon Lewin, Helen Smith, Mark Engel, Atle Fretheim, and Jimmy Volmink. 2008.

"Conducting a Meta-ethnography of Qualitative Literature: Lessons Learnt.” BMC Medical Research Methodology 8 (1): 21. doi:10.1186/1471-2288-8-21.

Barbour, Rosaline S., and Michael Barbour. 2003. "Evaluating and Synthesizing Qualitative Research: The Need to Develop a Distinctive Approach." Journal of Evaluation in Clinical Practice 9 (2): 179-186. doi:10.1046/j.1365-2753.2003.00371.x.

Berman, Helene, Marilyn Ford-Gilboe, Beth Moutrey, and Saira Cekic. 2001. "Portraits of Pain and Promise: A Photographic Study of Bosnian Youth." Canadian Journal of Nursing Research 32 (4): 21-41.

Betancourt, Theresa S. 2005. "Stressors, Supports and the Social Ecology of Displacement: Psychosocial Dimensions of an Emergency Education Program for Chechen Adolescents Displaced in Ingushetia, Russia.” Culture, Medicine \& Psychiatry 29 (3): 309-340. doi:10.1007/s11013-005-9170-9.

Betancourt, Theresa S., Saida Abdi, Brandson S. Ito, Grace M. Lilienthal, Naima Agalab, and Heidi Ellis. 2015. "We Left One War and Came to Another: Resource Loss, Acculturative Stress, and Caregiver-Child Relationships in Somali Refugee Families." Cultural Diversity and Ethnic Minority Psychology 21 (1): 114-125. doi:10.1037/a0037538.

Betancourt, Theresa S., and Kashif T. Khan. 2008. "The Mental Health of Children Affected by Armed Conflict: Protective Processes and Pathways to Resilience." International Review of Psychiatry 20 (3): 317-328. 
Sleijpen, M., Boeije, H.R., Kleber, R.J., Mooren, T. Between power and powerlessness: a metaethnography of sources of resilience in young refugees. Ethnicity and Health: 2016, 21(2), 158180

Block, Jeanne H., and Jack Block. 1980. "The Role of Ego-control and Ego Resiliency in the Organization of Behaviour." In Minnesota Symposium on Child Psychology, edited by W.

Andrew Collins, 39-101. Hillsdale, NJ: Lawrence Erlbaum Associates.

Boeije, Hennie R., Floryt van Wesel, and Eva Alisic. 2011. "Making a Difference: Towards a Method for Weighing the Evidence in a Qualitative Synthesis." Journal of Evaluation in Clinical Practice 17 (4): 657-663. doi:10.1111/j.1365-2753.2011.01674.x.

Boeije, Hennie R., Floryt van Wesel, and Meike Slagt. 2014. "Guidance for Deciding upon Use of Primary Mixed Methods Studies in Research Synthesis: Lessons Learned in Childhood Trauma.” Quality \& Quantity 48 (2): 1075-1088. doi:10.1007/s11135-0129825-x.

Bolea, Patty S., George Grant, Jr., Marcy Burgess, and Olja Plasa. 2003. "Trauma of Children of The Sudan: A Constructivist Exploration.” Child Welfare 82 (2): 219-233.

Booth, Andrew, Christopher Carroll, Irene Ilott, Lee L. Low, and Katy Cooper. 2013. Desperately Seeking Dissonance Identifying the Disconfirming Case in Qualitative Evidence Synthesis." Qualitative Health Research 23 (1): 126-141. doi:10.1177/1049732312466295.

Bracken, Patrick J., Joan E. Giller, and Derek Summerfield. 1995. "Psychological Responses to War and Atrocity: The Limitations of Current Concepts." Social Science and Medicine 40 (8): 1073-1082. doi:10.1016/0277-9536(94)00181-R.

Brom, Danny, and Rolf J. Kleber. 2009. "Resilience as the Capacity for Processing Traumatic Experiences.” In Treating Traumatized Children: Risk, Resilience and Recovery, edited by Danny Brom, Ruth Pat-Horenczyk, and Julian D. Ford, 133-149. New York: Routledge.

Bronstein, Israel, and Paul Montgomery. 2011. "Psychological Distress in Refugee Children: A Systematic Review.” Clinical Child and Family Psychology Review 14 (1):4456. doi:10.1007/ s10567-010-0081-0 Bronstein, Israel, Paul Montgomery, and Eleanor Ott. 2013. "Emotional and Behavioural Problems amongst Afghan Unaccompanied Asylumseeking Children: Results from a Large-scale Crosssectional Study." European Child and Adolescent Psychiatry 22 (5): 285-94. doi:10.1007/ s00787-012-0344-z Campbell, Rona, Pandora Pound, Catherine Pope, Nicky Britten, Roisin Pill, Myfanwy Morgan, and Jenny Donovan. 2003. "Evaluating Meta-ethnography: A Synthesis of Qualitative Research on Lay Experiences of Diabetes and Diabetes Care." Social Science \& Medicine 56 (4): 671 684. doi:10.1016/S0277-9536(02)00064-3.

Clay, Rebecca, Jacky Knibbs, and Stephen Joseph. 2009. "Measurement of Posttraumatic Growth in Young People: A Review." Clinical Child Psychology and Psychiatry 14 (3): 411-422.

doi:10.1177/1359104509104049.

Dixon-Woods, Mary, Shona Agarwal, David Jones, Bridget Young, and Alex Sutton. 2005. "Synthesising Qualitative and Quantitative Evidence: A Review of Possible Methods." Journal of Health Services Research and Policy 10 (1): 45-53. doi:10.1258/1355819052801804.

Doyle, Lynn H. 2003. " "Synthesis through Meta-ethnography: Paradoxes, Enhancements, and Possibilities." Qualitative Research 3 (3): 321-344. doi:10.1177/1468794103033003. Ellis, B. Heidi, Alisa K. Lincoln, Meredith E. Charney, Rebecca Ford-Paz, Molly Benson, and Lee Strunin. 2010. "Mental Health Service Utilization of Somali Adolescents: Religion, Community, and School as Gateways to Healing." Transcultural Psychiatry 47 (5): 789 811. doi:10.1177/ 1363461510379933 Ellis, B. Heidi, Helen Z. MacDonald, Julie Klunk Gillis, Alisa Lincoln, Lee Strunin, and Howard J.

Cabral. 2010. "Discrimination and Mental Health among Somali Refugee Adolescents: The Role of Acculturation and Gender." American Journal of Orthopsychiatry 80 (4): 564-575. doi:10.1111/j.1939-0025.2010.01061.x. 
Sleijpen, M., Boeije, H.R., Kleber, R.J., Mooren, T. Between power and powerlessness: a metaethnography of sources of resilience in young refugees. Ethnicity and Health: 2016, 21(2), 158180

Fazel, Mina, Ruth V. Reed, Catherine Panter-Brick, and Alan Stein. 2012. "Mental Health of Displaced and Refugee Children Resettled in High-income Countries: Risk and Protective Factors.” The Lancet 379 (9812): 266-282.

France, Emma F., Nicola Ring, Rebecca Thomas, Jane Noyes, Margaret Maxwell, and Ruth Jepson.

2014. "A Methodological Systematic Review of What' s Wrong with Meta-ethnography Reporting.” BMC Medical Research Methodology 14 (1): 119. doi:10.1186/1471-2288-14119.

Gibson, Eliza C. 2002. "The Impact of Political Violence: Adaptation and Identity Development in Bosnian Adolescent Refugees." Smith College Studies in Social Work 73 (1): 29-50.

Goodman, Janice H. 2004. "Coping with Trauma and Hardship among Unaccompanied Refugee Youths from Sudan.” Qualitative Health Research 14 (9): 1177-1196. doi:10.1177/ 1049732304265923.

Gorman, Don, Mark Brough, and Elvia Ramirez. 2003. "How Young People from Culturally and Linguistically Diverse Backgrounds Experience Mental Health: Some Insights for Mental Health Nurses.” International Journal of Mental Health Nursing 12 (3): 194-202. doi:10.1046/j.1440- 0979.2003.00289.x.

Groark, Claire, Irene Sclare, and Hitesh Raval. 2011. "Understanding the Experiences and Emotional Needs of Unaccompanied Asylum-seeking Adolescents in the UK." Clinical Child Psychology and Psychiatry 16 (3): 421-442. doi:10.1177/1359104510370405.

Gustafsson, Kristina, Ingrid Fioretos, and Eva Norström. 2012. "Between Empowerment and Powerlessness: Separated Minors in Sweden." New Directions for Child and Adolescent Development 136: 65-77.

Hannes, Karin, and Angela Harden. 2011. "Multi - context versus Context - specific Qualitative Evidence Syntheses: Combining the Best of Both.” Research Synthesis Methods 2 (4): 271-278.

doi:10.1002/jrsm.55.

Henley, Joh, and Julie Robinson. 2011. "Mental Health Issues among Refugee Children and Adolescents." Clinical Psychologist 15 (2): 51-62. doi:10.1111/j.17429552.2011.00024.x.

Hinton, Rachel. 2000. "Seen but Not Heard: Refugee Children and Models for Intervention. ” In Abandoned Children, edited by Catherine Panter-Brickand Malcolm T. Smith, 199212.

Cambridge: Cambridge University Press.

Hodes, Matthew. 2000. "Psychologically Distressed Refugee Children in the United Kingdom.” Child Psychology \& Psychiatry Review 5 (2): 57-68. doi:10.1017/S136064170000215X.

Hyman, I., Nhi Vu, and Morton Beiser. 2000. "Post-migration Stresses among Southeast Asian Refugee Youth in Canada: A Research Note." Journal of Comparative Family Studies 31 (2): 281-293.

Kapoulas, Alexandros, and Miljana Mitic. 2012. "Understanding Challenges of Qualitative Research: Rhetorical Issues and Reality Traps.” Journal Qualitative Market Research: An International Journal 15 (4): 354-368. doi:10.1108/13522751211257051.

Kinzie, J. David, William H. Sack, Richard H. Angell, Spero Manson, and Ben Rath. 1986 . “ The Psychiatric Effects of Massive Trauma on Cambodian Children: I. The Children." Journal of the American Academy of Child Psychiatry 25 (3): 370-376. doi:10.1016/S00027138(09) 60259-4.

Kleber, Rolf J. 1995. "Epilogue: Towards a Broader Perspective of Traumatic Stress." In Beyond Trauma: Cultural and Societal Dimensions, edited by Rolf J. Kleber, Charlos R. Figley, and Berthold P. R. Gersons, 299-306. New York: Plenum.

Kleber, Rolf J., and Danny Brom. 2003. Coping with Trauma: Theory, Prevention and Treatment. 
Sleijpen, M., Boeije, H.R., Kleber, R.J., Mooren, T. Between power and powerlessness: a metaethnography of sources of resilience in young refugees. Ethnicity and Health: 2016, 21(2), 158180

Abingdon: Taylor \& Francis.

Knipscheer, Jeroen W., and Rolf J. Kleber. 2006. "The Relative Contribution of Posttraumatic and Acculturative Stress to Subjective Mental Health among Bosnian Refugees.” Journal of Clinical Psychology 62 (3): 339-354. doi:10.1002/jclp.20233.

Leavey, Gerard, Kathryn Hollins, Michael King, Jacqueline Barnes, Christopher Papadopoulos, and Kate Grayson. 2004. "Psychological Disorder amongst Refugee and Migrant Schoolchildren in London." Social Psychiatry and Psychiatric Epidemiology 39 (3): 191-195. doi:10.1007/s00127- 004-0724-x.

Letts, Lori, Seanne Wilkins, M. Law, D. Stewart, J. Bosch, and M. Westmorland. 2007a. Critical Review Form - Qualitative Studies (Version 2.0). Occupational Therapy Evidencebased Practice Group.” McMaster University. Accessed June 2, 2013. http://www.srsmcmaster.ca/Portals/20/ pdf/ebp/qualreview_version2.0.pdf.

Letts, Lori, Seanne Wilkins, M. Law, D. Stewart, J. Bosch, and M. Westmorland. 2007b. "Guidelines for Critical Review Form - Qualitative Studies (Version 2.0). Occupational Therapy Evidence-based Practice Group.” McMaster University. Accessed June 2, 2013. http://www.srsmcmaster. ca/Portals/20/pdf/ebp/qualguidelines_version2.0.pdf.

Lustig, Stuart L., Maryam Kia-Keating, Wanda Grant Knight, Paul Geltman, Heidi Ellis, J.

David Kinzie, Terence Keane, and Glenn N. Saxe. 2004. "Review of Child and Adolescent Refugee Mental Health.” Journal of the American Academy of Child and Adolescent Psychiatry 43 (1): 24-36. doi:10.1097/00004583-200401000-00012.

Luthar, Suniya S., Dante Cicchetti, and Bronwyn Becker. 2000. "The Construct of Resilience: A Critical Evaluation and Guidelines for Future Work." Child Development 71 (3): 543-562.

doi:10.1111/1467-8624.00164.

Masten, Ann S. 2001. "Ordinary Magic: Resilience Processes in Development." American Psychologist 56 (3): 227-238.

Mazumdar, Shampa, and Sanjoy Mazumdar. 2009. "Religion, Immigration, and Home Making in Diaspora: Hindu Space in Southern California." Journal of Environmental Psychology 29 (2): 256-266. doi:10.1016/j.jenvp.2008.07.004.

McCarthy, Catherine, and David F. Marks. 2010. "Exploring the Health and Well-being of Refugee and Asylum Seeking Children.” Journal of Health Psychology 15 (4): 586-595. doi:10.1177/ 1359105309353644.

McMullen, John D., Paul S. O' Callaghan, Justin A. Richards, John G. Eakin, and Harry Rafferty.

2012. "Screening for Traumatic Exposure and Psychological Distress among War-affected Adolescents in Post-conflict Northern Uganda." Social Psychiatry and Psychiatric Epidemiology 47 (9): 1489-1498. doi:10.1007/s00127-011-0454-9.

Mels, Cindy, Ilse Derluyn, and Eric Broekaert. 2008. "Social Support in Unaccompanied Asylumseeking Boys: A Case Study.” Child: Care, Health and Development 34 (6): 757 762.

doi:10.1111/j.1365-2214.2008.00883.x.

Merali, Noorfarah. 2004. "Family Experiences of Central American Refugees Who Overestimate Intergenerational Gaps.” Canadian Journal of Counselling 38 (2): 91-103.

Merali, Noorfarah. 2005. "Perceived Experiences of Central American Refugees Who Favourably Judge the Family' s Cultural Transition Process." International Journal for the Advancement of Counselling 27 (3): 345-357. doi:10.1007/s10447-005-8198-4.

Michaud, Pierre-André. 2006. "Adolescents and Risks: Why Not Change Our Paradigm?" Journal of Adolescent Health 38 (5): 481-483.

Ndengeyingoma, Assumpta, Francine de Montigny, and Jean-Marie Miron. 2013. Development of Personal Identity among Refugee Adolescents: Facilitating Elements and Obstacles." Journal of Child Health Care 18(4): 369-377. doi:10.1177/1367493513496670. 
Sleijpen, M., Boeije, H.R., Kleber, R.J., Mooren, T. Between power and powerlessness: a metaethnography of sources of resilience in young refugees. Ethnicity and Health: 2016, 21(2), 158180

Ní Raghallaigh, Muireann, and Robbie Gilligan. 2010. "Active Survival in the Lives of Unaccompanied Minors: Coping Strategies, Resilience, and the Relevance of Religion." Child and Family Social Work 15 (2): 226-237.

Ní Raghallaigh, Muireann. 2011. "Religion in the Lives of Unaccompanied Minors: An Available and Compelling Coping Resource." British Journal of Social Work 41 (3): 539556.

Noblit, George W., and R. Dwight Hare. 1988. Meta-ethnography: Synthesizing Qualitative Studies. Newbury Park, CA: Sage.

O' Higgins, Aoife. 2012. "Vulnerability and Agency: Beyond an Irreconcilable Dichotomy for Social Service Providers Working with Young Refugees in the UK." New Directions for Child and Adolescent Development 2012 (136): 79-91.

Pacione, Laura, Toby Measham, and Cécile Rousseau. 2013. "Refugee Children: Mental Health and Effective Interventions." Current Psychiatry Reports 15: 1-9. doi:10.1007/s11920-012-0341-4.

Papadopoulos, Renos. 1999. "Working with Bosnian Medical Evacuees and Their Families: Therapeutic Dilemmas.” Clinical Child Psychology and Psychiatry 4 (1): 107-120. doi:10.1177/ 1359104599004001009.

Phan, Tan. 2003. "Life in School: Narratives of Resiliency among Vietnamese-Canadian Youths.” Adolescence 38 (151): 555-566.

Poppitt, Gillian, and Ron Frey. 2007. "Sudanese Adolescent Refugees: Acculturation and Acculturative Stress.” Australian Journal of Guidance \& Counselling 17 (2): 160-181. doi:10.1375/ajgc.17.2.160.

Porter, Matthew, and Nick Haslam. 2005. "Predisplacement and Postdisplacement Factors Associated with Mental Health of Refugees and Internally Displaced Persons: A Metaanalysis.” Journal of the American Medical Association 294 (5): 602-612. doi:10.1001/jama.294.5.602.

Prilleltensky, Isaac. 1993. "The Immigration Experience of Latin American Families: Research and Action on Perceived Risk and Protective Factors." Canadian Journal of Community Mental Health 12 (2): 101-116. doi:10.7870/cjcmh-1993-0021.

Reed, Ruth V., Mina Fazel, Lynne Jones, Catherine Panter-Brick, and Alan Stein. 2012. Mental Health of Displaced and Refugee Children Resettled in Low-Income and MiddleIncome Countries: Risk and Protective Factors.” The Lancet 379 (9812): 250-265.

Richman, Naomi. 1993. "Annotation: Children in Situations of Political Violence." Journal of Child Psychology and Psychiatry and Allied Disciplines 34 (8): 1286-1302. doi:10.1111/j.1469- 7610.1993.tb02092.x.

Rousseau, Cécile, Taher M. Said, Marie-Josée Gagné, and Gilles Bibeau. 1998. Resilience in Unaccompanied Minors from the North of Somalia." Psychoanalytic Review 85: 615-637.

Ryan, Dermot A., Ciarán A. Benson, and Barbara A. Dooley. 2008. "Psychological Distress and the Asylum Process: A Longitudinal Study of Forced Migrants in Ireland." The Journal of Nervous and Mental Disease 196 (1): 37-45. doi:10.1097/NMD.0b013e31815fa51c.

Sampson, Robyn, and Sandra M. Gifford. 2010. "Place-making, Settlement and Well-being: The Therapeutic Landscapes of Recently Arrived Youth with Refugee Backgrounds." Health \& Place 16 (1): 116-131. doi:10.1016/j.healthplace.2009.09.004.

Schapiro, Ann. 1988. "Adjustment and Identity Formation of Lao Refugee Adolescents." Smith College Studies in Social Work 58 (3): 157-181. doi:10.1080/00377318809516642. Silove, Derrick, Zachary Steel, Patrick McGorry, and P. Mohan. 1998. "Trauma Exposure, Postmigration Stressors, and Symptoms of Anxiety, Depression and Post - traumatic Stress in Tamil Asylum - seekers: Comparison with Refugees and Immigrants." Acta Psychiatrica Scandinavica 97 (3): 175-181. doi:10.1111/j.1600-0447.1998.tb09984.x. Sleijpen, Marieke, F. Jackie June ter Heide, Trudy Mooren, Hennie R. Boeije, and Rolf J. Kleber. 
Sleijpen, M., Boeije, H.R., Kleber, R.J., Mooren, T. Between power and powerlessness: a metaethnography of sources of resilience in young refugees. Ethnicity and Health: 2016, 21(2), 158180

2013. "Bouncing Forward of Young Refugees: A Perspective on Resilience Research Directions.” European Journal of Psychotraumatology 4. doi:10.3402/ejpt.v4i0.20124.

Smith, Lucy K., Catherine Pope, and Johannes L. Botha. 2005. "Patients' Help-seeking Experiences and Delay in Cancer Presentation: A Qualitative Synthesis.” Lancet 366 (9488): 825-831. doi:10.1016/S0140-6736(05)67030-4.

Sutton, Vicky, lan Robbins, Vicky Senior, and Sedwick Gordon. 2006. “A Qualitative Study Exploring Refugee Minors' Personal Accounts of Post-Traumatic Growth and Positive Change Processes in Adapting to Life in the UK." Diversity in Health and Social Care 3 (2): 77-88.

Tedeschi, Richard G., and Lawrence G. Calhoun. 2004. "Posttraumatic Growth: Conceptual Foundations and Empirical Evidence.” Psychological Inquiry 15 (1): 1-18. Thomas, James, and Angela Harden. 2008. "Methods for the Thematic Synthesis of Qualitative Research in Systematic Reviews.” BMC Medical Research Methodology 8 (1): 45. doi:10.1186/ 1471-2288-8-45.

Thommesssen, Amalie O' Toole, Paula Corcoran, and Brenda K. Todd. 2015.

Experiences of Arriving to Sweden as an Unaccompanied Asylum-seeking Minor from Afghanistan: An Interpretative Phenomenological Analysis.” Psychology of Violence. Advance online publication. doi:10.1037/a0038842.

Tihabano, Kagiso N., and Robert Schweitzer. 2007. "A Qualitative Study of the Career Aspirations of Resettled Young Sudanese and Somali Refugees.” Journal of Psychology in Africa 17 (1): 13-22.

Ungar, Michael. 2003. "Qualitative Contributions to Resilience Research." Qualitative Social Work 2 (1): 85-102. doi:10.1177/1473325003002001123.

Ungar, Michael. 2011. "Community Resilience for Youth and Families: Facilitative Physical and Social Capital in Contexts of Adversity." Children and Youth Services Review 33 (9): $1742-1748$.

doi:10.1016/j.childyouth.2011.04.027.

Ungar, Michael. 2012. "Researching and Theorizing Resilience across Cultures and Contexts.” Preventive Medicine 55 (5): 387-389. doi:10.1016/j.ypmed.2012.07.021.

Ungar, Michael, and Gillian Nichol. 2002. "The Harmony of Resistance: Qualitative Research and Ethical Practice in Social Work." In Walking the Tightrope: Ethical Issues for Qualitative Researchers, edited by Will C. van den Hoonaard, 137-151. Toronto: University of Toronto Press.

Weine, Stevan M., Norma Ware, Leonce Hakizimana, Toni Tugenberg, Medeleine Currie, Gonwo Dahnweih, Maureem Wagner, Chloe Polutnik, and Jacqueline Wulu. 2014. " Fostering Resilience: Protective Agents, Resources, and Mechanisms for Adolescent Refugees' Psychosocial Well- Being.” Adolescent Psychiatry (Hilversum) 4 (4): 164176.

Weine, Stevan M., Norma Ware, and Alma Klebic. 2004. "Converting Cultural Capital Among Teen Refugees and Their Families From Bosnia-Herzegovina." Psychiatric Services 55 (8): 923- 927. doi:10.1176/appi.ps.55.8.923.

Weine, Stevan M., Norma Ware, Toni Tugenberg, Leonce Hakizimana, Gonwo Dahnweih, Madeleine Currie, Maureen Wagner, and Elise Levin. 2013. "Thriving, Managing, and Struggling: A Mixed Methods Study of Adolescent African Refugees' Psychosocial Adjustment." Adolescent Psychiatry 3 (1): 72-81.

Wyman, Peter A. 2003. "Emerging Perspectives on Context Specificity of Children's Adaptation and Resilience: Evidence from a Decade of Research with Urban Children in Adversity." In Resilience and Vulnerability: Adaptation in the Context of Childhood Adversities, edited by Suniya S. Luthar, 293-317. New York: Cambridge University Press. 
Sleijpen, M., Boeije, H.R., Kleber, R.J., Mooren, T. Between power and powerlessness: a metaethnography of sources of resilience in young refugees. Ethnicity and Health: 2016, 21(2), 158180

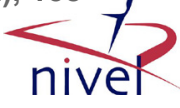

TABLES AND FIGURES

Table 1. Search terms.

\begin{tabular}{|c|c|c|c|c|c|c|c|c|c|}
\hline \multirow[b]{2}{*}{$\begin{array}{l}\text { Boolean } \\
\text { operators }\end{array}$} & \multicolumn{9}{|c|}{ Search terms } \\
\hline & OR & OR & OR & OR & OR & OR & OR & OR & OR \\
\hline & Refugee & $\begin{array}{l}\text { Asylum } \\
\text { seeker }\end{array}$ & $\begin{array}{l}\text { Displaced } \\
\text { person }\end{array}$ & $\begin{array}{l}\text { Ethnic } \\
\text { minorities }\end{array}$ & $\begin{array}{l}\text { Ethnic } \\
\text { minority }\end{array}$ & & & & \\
\hline AND & Adolescent & Adolescence & Pubescent & Youngster & Young & Youth & Teenager & $\begin{array}{l}\text { Person in } \\
\text { puberty }\end{array}$ & Child \\
\hline \multirow[t]{2}{*}{ AND } & $\begin{array}{l}\text { Qualitative } \\
\text { research }\end{array}$ & Qualitatively & $\begin{array}{l}\text { Qualitative } \\
\text { analyses }\end{array}$ & Interview & $\begin{array}{l}\text { Unstructured } \\
\text { interview }\end{array}$ & $\begin{array}{l}\text { Open } \\
\text { interview }\end{array}$ & $\begin{array}{l}\text { In-depth } \\
\text { interview }\end{array}$ & $\begin{array}{l}\text { Semi-structured } \\
\text { interview }\end{array}$ & $\begin{array}{l}\text { Semi-structured } \\
\text { interview }\end{array}$ \\
\hline & $\begin{array}{l}\text { Semi- } \\
\text { structured }\end{array}$ & $\begin{array}{l}\text { Open } \\
\text { question }\end{array}$ & Focus group & $\begin{array}{l}\text { Participant } \\
\text { observation }\end{array}$ & $\begin{array}{l}\text { Participatory } \\
\text { research }\end{array}$ & $\begin{array}{l}\text { Mixed } \\
\text { method }\end{array}$ & $\begin{array}{l}\text { Grounded } \\
\text { theory }\end{array}$ & Ethnographic & Ethnography \\
\hline \multirow[t]{3}{*}{ AND } & Resilience & Resilient & Resiliency & Coping & $\begin{array}{l}\text { Protective } \\
\text { resource }\end{array}$ & $\begin{array}{l}\text { Protective } \\
\text { factor }\end{array}$ & Adaptation & Adaptability & Reacclimatize \\
\hline & Acculturation & Support & $\begin{array}{l}\text { Inner } \\
\text { strength }\end{array}$ & Mastery & Self-esteem & $\begin{array}{l}\text { Self- } \\
\text { respect }\end{array}$ & Well-being & Well-being & Life satisfaction \\
\hline & $\begin{array}{l}\text { Future } \\
\text { expectation }\end{array}$ & Desire & Ambition & $\begin{array}{l}\text { Posttraumatic } \\
\text { growth }\end{array}$ & $\begin{array}{l}\text { Posttraumatic } \\
\text { growth }\end{array}$ & & & & \\
\hline
\end{tabular}

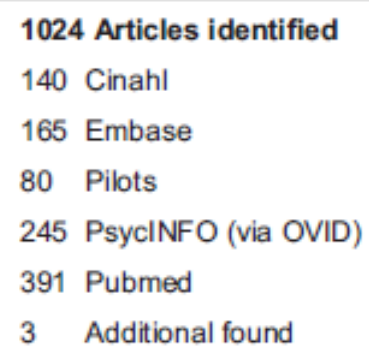

666 Articles excluded on the basis of source and title

262 Duplicate articles

147 Editorials, book chapters, newspaper articles or dissertation chapters

6 Not in English language

251 Article is outside scope of the review

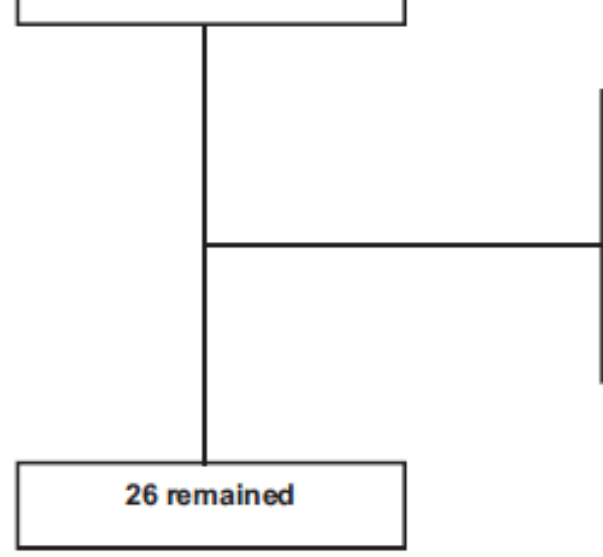
332 Articles exclu
102 Different topic
125 Not focused on adolescents
83 Not qualitative research
22 Not addressing refugees

Figure 1. Search strategy and article review process. 
Sleijpen, M., Boeije, H.R., Kleber, R.J., Mooren, T. Between power and powerlessness: a metaethnography of sources of resilience in young refugees. Ethnicity and Health: 2016, 21(2), 158180

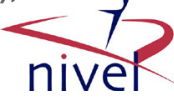

Table 2. Descriptive characteristic of included studies.

\begin{tabular}{|c|c|c|c|c|c|c|}
\hline Authors & Study population & $\begin{array}{c}\text { Land of } \\
\text { immigration }\end{array}$ & Research topics & $\begin{array}{l}\text { Number of young } \\
\text { refugees participating in } \\
\text { the qualitative research } \\
\text { component }\end{array}$ & $\begin{array}{l}\text { Age of } \\
\text { young } \\
\text { refugees }\end{array}$ & Data collection method \\
\hline $\begin{array}{l}\text { (1) Anstiss and } \\
\text { Ziaian (2010) }\end{array}$ & $\begin{array}{l}\text { Refugee } \\
\text { adolescents }\end{array}$ & Australia & $\begin{array}{l}\text { Mental health } \\
\text { help-seeking }\end{array}$ & 85 & $13-17$ & $\begin{array}{l}\text { Mixed methods; qualitative component: } \\
\text { focus groups }\end{array}$ \\
\hline $\begin{array}{l}\text { (2) Berman } \\
\text { et al. }(2001)\end{array}$ & Bosnian youth & Canada & $\begin{array}{l}\text { Everyday } \\
\text { challenges and } \\
\text { struggles }\end{array}$ & 7 & $11-14$ & $\begin{array}{l}\text { Photo novella in combination with in- } \\
\text { depth dialogic interviews }\end{array}$ \\
\hline $\begin{array}{l}\text { (3) Bolea } \\
\text { et al. (2003) }\end{array}$ & $\begin{array}{l}\text { Sudanese male } \\
\text { children }\end{array}$ & USA & $\begin{array}{l}\text { Trauma and } \\
\text { adjustment to } \\
\text { the USA }\end{array}$ & 4 & $>10-18$ & Qualitative interviews \\
\hline $\begin{array}{l}\text { (4) Ellis, Lincoln, } \\
\text { et al. (2010) }\end{array}$ & $\begin{array}{l}\text { Somali refugee } \\
\text { adolescents }\end{array}$ & USA & $\begin{array}{l}\text { Mental health } \\
\text { service utilization }\end{array}$ & 30 & $11-20$ & $\begin{array}{l}\text { Mixed methods; qualitative component: } \\
\text { focus groups and in-depth interviews }\end{array}$ \\
\hline $\begin{array}{l}\text { (5) Ellis, } \\
\text { MacDonald, } \\
\text { et al. (2010) }\end{array}$ & $\begin{array}{l}\text { Somali refugee } \\
\text { adolescents }\end{array}$ & USA & $\begin{array}{l}\text { Discrimination } \\
\text { and mental health }\end{array}$ & 30 & $11-20$ & $\begin{array}{l}\text { Mixed methods; qualitative component: } \\
\text { focus groups and in-depth interviews }\end{array}$ \\
\hline (6) Gibson (2002) & $\begin{array}{l}\text { Bosnian } \\
\text { adolescent } \\
\text { refugees }\end{array}$ & USA & $\begin{array}{l}\text { Adaptation and } \\
\text { identity } \\
\text { development }\end{array}$ & 5 & $14-18$ & In-depth interviews \\
\hline (7) Goodman (2004) & $\begin{array}{l}\text { Unaccompanied } \\
\text { Sudanese refugee } \\
\text { male youth }\end{array}$ & USA & $\begin{array}{l}\text { Coping with } \\
\text { trauma and } \\
\text { hardship }\end{array}$ & 14 & $16-18$ & $\begin{array}{l}\text { Unstructured interviews with broad, } \\
\text { open-ended questions }\end{array}$ \\
\hline $\begin{array}{l}\text { (8) Gorman, } \\
\text { Brough, and } \\
\text { Ramirez (2003) }\end{array}$ & $\begin{array}{l}\text { Culturally and } \\
\text { linguistically } \\
\text { diverse young } \\
\text { people (CALD) }\end{array}$ & Australia & $\begin{array}{l}\text { Experiences with } \\
\text { mental } \\
\text { health care }\end{array}$ & 123 & $16-24$ & In-depth interviews \\
\hline $\begin{array}{l}\text { (9) Groark, Sclare, } \\
\text { and Raval (2011) }\end{array}$ & $\begin{array}{l}\text { Unaccompanied } \\
\text { asylum-seeking } \\
\text { adolescents }\end{array}$ & UK & $\begin{array}{l}\text { The experiences } \\
\text { of seeking } \\
\text { asylum and } \\
\text { emotional needs }\end{array}$ & 6 & $16-18$ & $\begin{array}{l}\text { Mixed methods; qualitative component: } \\
\text { semi-structured interviews }\end{array}$ \\
\hline $\begin{array}{l}\text { (10) Hyman and } \\
\text { Beiser (2000) }\end{array}$ & $\begin{array}{l}\text { Southeast Asian } \\
\text { refugee youth }\end{array}$ & Canada & $\begin{array}{l}\text { Post-migration } \\
\text { stresses }\end{array}$ & $\begin{array}{l}16 \text { (individual interviews) } \\
10-25 \text { (per focus group) }\end{array}$ & $15-20$ & $\begin{array}{l}\text { Semi-structured individual interviews } \\
\text { and semi-structured focus groups }\end{array}$ \\
\hline
\end{tabular}

Table 2 (Continued)

\begin{tabular}{|c|c|c|c|c|c|c|}
\hline Authors & Study population & $\begin{array}{l}\text { Land of } \\
\text { immigration }\end{array}$ & Research topics & $\begin{array}{l}\text { Number of young } \\
\text { refugees participating in } \\
\text { the qualitative research } \\
\text { component }\end{array}$ & $\begin{array}{l}\text { Age of } \\
\text { young } \\
\text { refugees }\end{array}$ & Data collection method \\
\hline $\begin{array}{l}\text { (11) McCarthy and } \\
\text { Marks (2010) }\end{array}$ & $\begin{array}{l}\text { Young refugees } \\
\text { and asylum } \\
\text { seekers }\end{array}$ & UK & $\begin{array}{l}\text { Health and well- } \\
\text { being }\end{array}$ & 16 & $10-21$ & Focus groups and interviews \\
\hline $\begin{array}{l}\text { (12) Mels, Derluyn, } \\
\text { and } \\
\text { Broekaert (2008) }\end{array}$ & $\begin{array}{l}\text { Unaccompanied } \\
\text { asylum-seeking } \\
\text { adolescent males }\end{array}$ & Belgium & Social support & 12 & $15-18$ & Semi-structured in-depth interviews \\
\hline (13) Merali (2004) & $\begin{array}{l}\text { Central American } \\
\text { refugee families }\end{array}$ & Canada & $\begin{array}{l}\text { Family } \\
\text { experiences after } \\
\text { immigration }\end{array}$ & 6 & $13-18$ & Interviews \\
\hline (14) Merali (2005) & $\begin{array}{l}\text { Central American } \\
\text { refugee families }\end{array}$ & Canada & $\begin{array}{l}\text { Family } \\
\text { experiences with } \\
\text { cultural transition }\end{array}$ & 6 & $12-18$ & Interviews \\
\hline $\begin{array}{l}\text { (15) Ní Raghallaigh } \\
\text { and } \\
\text { Gilligan (2010) }\end{array}$ & $\begin{array}{l}\text { Unaccompanied } \\
\text { minors from } 13 \\
\text { different countries }\end{array}$ & Ireland & $\begin{array}{l}\text { Coping strategies } \\
\text { and resilience }\end{array}$ & 32 & $14-19$ & In-depth qualitative interviews \\
\hline $\begin{array}{l}\text { (16) Ní } \\
\text { Raghallaigh } \\
\text { (2011) }\end{array}$ & $\begin{array}{l}\text { Unaccompanied } \\
\text { minors from } 13 \\
\text { different countries }\end{array}$ & Ireland & Religious coping & 32 & $14-19$ & Semi-structured interviews \\
\hline (17) Phan (2003) & $\begin{array}{l}\text { Vietnamese- } \\
\text { Canadian youth }\end{array}$ & Canada & $\begin{array}{l}\text { Narratives of } \\
\text { resiliency }\end{array}$ & 11 & $17-18$ & Repeated interviews \\
\hline $\begin{array}{l}\text { (18) Poppitt and } \\
\text { Frey (2007) }\end{array}$ & $\begin{array}{l}\text { Sudanese } \\
\text { adolescent } \\
\text { refugees }\end{array}$ & Australia & $\begin{array}{l}\text { Acculturation and } \\
\text { acculturative } \\
\text { stress }\end{array}$ & 20 & $13-18$ & Semi- structured interviews \\
\hline $\begin{array}{l}\text { (19) Prilleltensky } \\
\text { (1993) }\end{array}$ & $\begin{array}{l}\text { Latin American } \\
\text { families }\end{array}$ & Canada & $\begin{array}{l}\text { Risk and } \\
\text { protective factors }\end{array}$ & 8 & $8-17$ & $\begin{array}{l}\text { Interviews and focus groups only by } \\
\text { adults }\end{array}$ \\
\hline $\begin{array}{l}\text { (20) Rousseau } \\
\text { et al. (1998) }\end{array}$ & $\begin{array}{l}\text { Young } \\
\text { unaccompanied } \\
\text { Somali refugee } \\
\text { adolescent males }\end{array}$ & Canada & Resilience & 10 & $13-18$ & $\begin{array}{l}\text { Unstructured and semi-structured } \\
\text { interviews }\end{array}$ \\
\hline
\end{tabular}


Sleijpen, M., Boeije, H.R., Kleber, R.J., Mooren, T. Between power and powerlessness: a metaethnography of sources of resilience in young refugees. Ethnicity and Health: 2016, 21(2), 158180

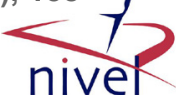

Table 2 (Continued)

\begin{tabular}{|c|c|c|c|c|c|c|}
\hline Authors & Study population & $\begin{array}{l}\text { Land of } \\
\text { immigration }\end{array}$ & Research topics & $\begin{array}{l}\text { Number of young } \\
\text { refugees participating in } \\
\text { the qualitative research } \\
\text { component }\end{array}$ & $\begin{array}{l}\text { Age of } \\
\text { young } \\
\text { refugees }\end{array}$ & Data collection method \\
\hline $\begin{array}{l}\text { (21) Sampson and } \\
\text { Gifford (2010) }\end{array}$ & $\begin{array}{l}\text { Recently arrived } \\
\text { youth with } \\
\text { refugee } \\
\text { backgrounds }\end{array}$ & Australia & $\begin{array}{l}\text { Place-making, } \\
\text { settlement and } \\
\text { well-being }\end{array}$ & 115 & $11-19$ & $\begin{array}{l}\text { Visual methods: neighborhood maps and } \\
\text { photo-novellas }\end{array}$ \\
\hline $\begin{array}{l}\text { (22) Schapiro } \\
\text { (1988) }\end{array}$ & $\begin{array}{l}\text { Lao refugee } \\
\text { adolescents }\end{array}$ & USA & $\begin{array}{l}\text { Adjustment and } \\
\text { identity } \\
\text { formation }\end{array}$ & 15 & $13-19$ & Open-ended structured interviews \\
\hline $\begin{array}{l}\text { (23) Sutton } \\
\text { et al. (2006) }\end{array}$ & $\begin{array}{l}\text { Unaccompanied } \\
\text { refugee minors }\end{array}$ & UK & $\begin{array}{l}\text { Process of } \\
\text { positive change } \\
\text { and posttraumatic } \\
\text { growth }\end{array}$ & 8 & $16-20$ & Semi-structured interviews \\
\hline $\begin{array}{l}\text { (24) Tihabano and } \\
\text { Schweitzer (2007) }\end{array}$ & $\begin{array}{l}\text { Resettled young } \\
\text { Sudanese and } \\
\text { Somali refugees }\end{array}$ & Australia & $\begin{array}{l}\text { Career } \\
\text { aspirations }\end{array}$ & 14 & $16-26$ & Qualitative interviews \\
\hline $\begin{array}{l}\text { (25) Weine, Ware, } \\
\text { and Klebic (2004) }\end{array}$ & $\begin{array}{l}\text { Bosnia- } \\
\text { Herzegovinian } \\
\text { refugees and their } \\
\text { families }\end{array}$ & USA & $\begin{array}{l}\text { Converting } \\
\text { cultural capital }\end{array}$ & 30 & $\begin{array}{l}\text { Not } \\
\text { reported }\end{array}$ & In-depth interviews andobservations \\
\hline $\begin{array}{l}\text { (26) Weine } \\
\text { et al. (2013) }\end{array}$ & $\begin{array}{l}\text { Burundian and } \\
\text { Liberian refugee } \\
\text { adolescents }\end{array}$ & USA & $\begin{array}{l}\text { Patterns of } \\
\text { psychosocial } \\
\text { adjustment }\end{array}$ & 73 & $10-19$ & $\begin{array}{l}\text { Mixed methods; qualitative component: } \\
\text { minimally-structured interviews, } \\
\text { shadowing observations, and focused } \\
\text { field observations }\end{array}$ \\
\hline
\end{tabular}

Table 3. Methodological quality of included studies $(N=26)$.

Quality criterion

\begin{tabular}{ccc}
$\begin{array}{c}\text { Meets } \\
\text { criterion }\end{array}$ & $\begin{array}{c}\text { Does not meet } \\
\text { criterion }\end{array}$ & $\begin{array}{c}\text { Not } \\
\text { addressed }\end{array}$ \\
\hline
\end{tabular}

Was the purpose and/or research question stated clearly?

Was relevant background literature reviewed?

Was a theoretical perspective identified?

Was the process of purposeful sample selection described?

Was sampling done until redundancy in data was reached?

Was informed consent obtained?

Was procedural rigor used in data collection strategies?

Were data analyses inductive?

Were findings consistent with and reflective of data?

Was the process of decision trail and of analyzing the data described adequately?

Did a meaningful picture emerge of the phenomenon under study?

Were conclusions appropriate given the study findings?
25

23

16

14

1

13

18

$\begin{array}{rr}5 & 1 \\ 3 & 3 \\ 6 & 10 \\ 4 & 12\end{array}$

3

10

12

\begin{tabular}{ll}
$-\quad 25$ \\
\hline
\end{tabular}

13

$21 \quad 5$

$8 \quad 18$

$18 \quad 8$

$21 \quad 5$ 
Sleijpen, M., Boeije, H.R., Kleber, R.J., Mooren, T. Between power and powerlessness: a metaethnography of sources of resilience in young refugees. Ethnicity and Health: 2016, 21(2), 158180

Table 4. Definitions and implementation of the seven phases of meta-ethnography.

Our implementation

(1) Getting started

(2) Deciding what is relevant to the initial interest

(3) Reading the studies

(4) Determining how the studies are related.

(5) Translating studies into one another

(6) Synthesizing translation

(7) Expressing the synthesis
We formulated our review question and determined that it could be addressed by a synthesis of qualitative research.

We defined the focus of our meta-ethnography, searched for relevant studies, and made decisions on exclusion and inclusion (MS; HB; TM). We also assessed the quality of the included studies (MS; HB).

We (MS; HB; TM) read the included studies to become familiar with them and started the process of extracting methodological information and themes relevant to our review question.

Two authors (MS; HB) independently coded five included studies to create a list of codes. To extract sources of resilience we examined the Results sections of the primary studies.

Findings were not reported in other sections of the studies. To extract cross-cultural similarities and differences we also examined the Discussion and Conclusion sections of the studies; this was because this information was sometimes located in these sections. Coding was conducted with the Maxqda 2010 (Verbi, Berlin) software program for qualitative data analysis. After the two authors had discussed the results of the five studies, one of them (MS) coded the other included articles. Subsequently, the two authors who had created the codes (MS; $\mathrm{HB}$ ) discussed the entire coding process and decided to do a reciprocal synthesis as well as a refutational synthesis.

Reciprocal translation was used, i.e., we compared the codes with respect to sources of resilience assigned to individual articles. In this way we uncovered the main concepts that resonated across articles. Two authors (MS; HB) grouped related codes into key sources of resilience.

In addition a refutational translation was used to detect areas of incongruence in the key sources. For example, in most studies parents were seen as a source of support; however some studies offered a divergent account in which parents were perceived by young refugees as a source of stress. One author (MS) assessed whether there were conflicting results within and between studies. Two authors (MS; HB) discussed the results of the refutation synthesis.

In this phase we moved from descriptive to explanatory analysis in order to develop an explanatory account of incongruencies found during the refutational synthesis and the mechanisms underlying resilience. We also conducted a comparative analysis of cultural differences and similarities in ways of dealing with adversity between and within studies (MS; HB).

We disseminated the results of the synthesis in publications (including texts and tables) and presented it to a professional audience. 
Sleijpen, M., Boeije, H.R., Kleber, R.J., Mooren, T. Between power and powerlessness: a metaethnography of sources of resilience in young refugees. Ethnicity and Health: 2016, 21(2), 158180

Table 5. Duality of sources of resilience.

\begin{tabular}{|c|c|c|c|}
\hline $\begin{array}{l}\text { Source of } \\
\text { resilience }\end{array}$ & & Positive aspect & Negative aspect \\
\hline \multicolumn{4}{|c|}{ Social support } \\
\hline & Family & $\begin{array}{l}\text { Support } \\
\text { Guide }\end{array}$ & Stress \\
\hline & $\begin{array}{l}\text { People with the } \\
\text { same cultural } \\
\text { background }\end{array}$ & $\begin{array}{l}\text { Support (recognition) } \\
\text { Reducing sense of } \\
\text { cultural loss }\end{array}$ & $\begin{array}{l}\text { Isolation from host } \\
\text { country }\end{array}$ \\
\hline & Peers & $\begin{array}{l}\text { Support } \\
\text { Distraction } \\
\text { Advice }\end{array}$ & Distrust \\
\hline & Professionals & $\begin{array}{l}\text { Support } \\
\text { (Practical) Advice }\end{array}$ & $\begin{array}{l}\text { Distrust } \\
\text { Social stigma }\end{array}$ \\
\hline \multicolumn{4}{|c|}{ Acculturation strategies } \\
\hline & $\begin{array}{l}\text { Connecting to the } \\
\text { culture of origin }\end{array}$ & Sense of continuity & $\begin{array}{l}\text { Isolation from host } \\
\text { country } \\
\text { Discrimination }\end{array}$ \\
\hline
\end{tabular}

Table 5 (Continued)

\begin{tabular}{|c|c|c|c|}
\hline $\begin{array}{l}\text { Source of } \\
\text { resilience }\end{array}$ & & Positive aspect & Negative aspect \\
\hline \multirow{2}{*}{ Education } & $\begin{array}{l}\text { Adaptation to the } \\
\text { new lifestyle }\end{array}$ & $\begin{array}{l}\text { Social acceptance } \\
\text { Strengthen sense } \\
\text { of self }\end{array}$ & $\begin{array}{l}\text { Disconnecting from } \\
\text { culture of origin } \\
\text { Intergenerational strains }\end{array}$ \\
\hline & & $\begin{array}{l}\text { Sense of control } \\
\text { Key to a higher status } \\
\text { Distraction } \\
\text { Hope }\end{array}$ & $\begin{array}{l}\text { High responsibility/fear of } \\
\text { failure }\end{array}$ \\
\hline \multicolumn{4}{|l|}{ Religion } \\
\hline & & $\begin{array}{l}\text { Guide } \\
\text { Giving meaning } \\
\text { Support } \\
\text { Sense of continuity } \\
\text { Distraction } \\
\text { Sense of control }\end{array}$ & $\begin{array}{l}\text { Being different from peers } \\
\text { Discrimination }\end{array}$ \\
\hline \multirow{2}{*}{ Avoidance } & Suppression & $\begin{array}{l}\text { Not overwhelmed by } \\
\text { memories } \\
\text { Continue with life }\end{array}$ & $\begin{array}{l}\text { Negative long-term } \\
\text { consequences }\end{array}$ \\
\hline & Distraction & $\begin{array}{l}\text { Suppressing difficult } \\
\text { thoughts }\end{array}$ & $\begin{array}{l}\text { Negative long-term } \\
\text { consequences }\end{array}$ \\
\hline Hope & & $\begin{array}{l}\text { Positivity } \\
\text { Facilitator to cope with } \\
\text { difficulties }\end{array}$ & \\
\hline
\end{tabular}

